\title{
Use of different Taq DNA polymerases for detection of Chlamydia trachomatis in cervical samples
}

O uso de diferentes Taq DNA polimerases para a detecção de Chlamydia trachomatis em amostras cervicais

El uso de diferentes Taq DNA polimerasas para la detección de Chlamydia trachomatis en muestras cervicales

Francisca Laís de Araújo Oliveira

Instituto de Saúde e Biotecnologia de Coari, Universidade Federal do Amazonas, Coari, Amazonas, Brasil

Maria Joana Nunes de Azevedo

Instituto de Saúde e Biotecnologia de Coari, Universidade Federal do Amazonas, Coari, Amazonas, Brasil

Anderson Nogueira Barbosa

Instituto de Saúde e Biotecnologia de Coari, Universidade Federal do Amazonas, Coari, Amazonas, Brasil
Rafael de Souza Rodrigues

Instituto de Saúde e Biotecnologia de Coari, Universidade Federal do Amazonas, Coari, Amazonas, Brasil

Renato dos Santos Reis

Instituto de Saúde e Biotecnologia de Coari, Universidade Federal do Amazonas, Coari, Amazonas, Brasil

Danielle Albuquerque Pires Rocha

Instituto de Saúde e Biotecnologia de Coari, Universidade Federal do Amazonas, Coari, Amazonas, Brasil

\begin{abstract}
INTRODUCTION: Chlamydia trachomatis is a small gram-negative bacterium sexually transmitted, which progresses asymptomatically in the majority of infected people, causing long-term damage mainly in the female reproductive system. The polymerase chain reaction (PCR) has been the diagnostic method most widely used in recent epidemiological studies by presenting superior sensitivity than the other sensitivity tests. For a good performance of PCR, the choice of enzymes is very important because they have different characteristics that influence their performance. OBJECTIVE: To analyze and compare the detection of C. trachomatis using three commercial enzymes Taq DNA polymerases in 280 cervical samples. METHODS: The enzymes used were: Taq DNA Polymerase Recombinant (Invitrogen, USA), Platinum ${ }^{\circledR}$ Taq DNA Polymerase (Invitrogen, USA) and Platinum ${ }^{\circledR}$ Taq DNA Polymerase High Fidelity (Invitrogen, USA). RESULTS: 280 cervical samples from women living in Coari City, Amazonas State, Brazil were analyzed, whose average age was 36.3 years old, the majority had low educational level, their first sexual intercourse was around 15.7 (SD = 0.7) with an average number of 3.7 children. $42.5 \%$ had clinical complaints during the visit, with a predominance of vaginal discharge, itching, pelvic pain and painful urination. Of the 280 samples, four (1.4\%) were positive using the recombinant Taq DNA polymerase, seven (2.5\%) using the enzyme Platinum ${ }^{\circledR}$ Taq DNA Polymerase and 11 (3.9\%) specimens were positive using Platinum ${ }^{\circledR}$ Taq DNA Polymerase High Fidelity. Statistical analysis showed no difference between groups $(p=0.186)$. CONCLUSION: Enzyme Taq DNA polymerases with different properties show differences in performance in the detection of $\mathrm{C}$. trachomatis.
\end{abstract}

Keywords: Taq Polymerase; Chlamydia trachomatis; Molecular Diagnostic Techniques.

\footnotetext{
Correspondence / Correspondência / Correspondencia:

Danielle Albuquerque Pires Rocha

Universidade Federal do Amazonas

Estrada Coari Mamiá, 305. Bairro: Espírito Santo

CEP: 69460-000 Coari-Amazonas-Brazil

E-mail:dannyodonto@hotmail.com
} 


\section{INTRODUCTION}

Chlamydia trachomatis is a bacterium belonging to the family Chlamydiaceae, genus Chlamydia, with Chlamydia pecorum, Chlamydia pneumoniae and Chlamydia psittaci, these latter two are also pathogenic in humans. This bacterium was considered to be a virus for many years because of its small size and its metabolic peculiarities. It is now known, however, that this is a small bacterium from 0.2 to $1.5 \mu \mathrm{m}$ in size, gram-negative, obligate intracellular parasite, devoid of motility which uses adenosine triphosphate (ATP) produced by the host cell for its survival ${ }^{1,2}$.

C. trachomatis is sexually transmitted and the leading cause of permanent infertility in women, occurring when the tubal damage is irreversible ${ }^{3}$. Other medical conditions caused by chlamydia are salpingitis, endometritis, pelvic inflammatory disease, ectopic pregnancy, premature birth, low birth weight, neonatal death, among other complications ${ }^{4}$.

In Brazil, the real prevalence of this infection is unknown because there is little official data on the epidemiology of sexually transmitted disease. The lack of populational studies and organized screening programs hinder the visibility of problems. Therefore, most of the available data comes from regional investigations, which, taken together, help to understand the profile of this silent infection ${ }^{4,5,6,7,8,9}$.

The methods used for diagnosis of chlamydia are cell culture, direct immunofluorescence, enzyme-linked immunosorbent assay (ELISA), Hybrid Capture and polymerase chain reaction (PCR). Of these, PCR has been widely used in recent epidemiological studies by presenting superior sensitivity than the other tests ${ }^{4,10}$. For a good performance of PCR, the choice of DNA polymerase is very important. Since its discovery, the Taq DNA polymerases have been improved over time, and today there are a variety of commercial enzymes to use in PCR.

Taq DNA polymerase is a recombinant thermostable enzyme that synthesizes DNA in the presence of dNTPs and a primer. The enzyme consists of a single polypeptide with a molecular weight of $94 \mathrm{kDa}$. The recombinant enzyme is purified from Thermus aquaticus polymerase gene and cloned in Escherichia coli. Platinum Taq DNA polymerase is an enzyme that has the technology of antibody bound to it, which blocks its action at room temperature and causes the separation between the enzyme and the antibody only during the initial denaturation at $94^{\circ} \mathrm{C}$ (Hot-Start technology). Thus, it avoids the synthesis of DNA from non-specific annealing at lower temperatures. The Platinum Taq DNA polymerase High Fidelity ( $\mathrm{HiFi}$ ) is an enzyme that has a high fidelity in the incorporation of nucleotides due to its activity revising $3^{\prime} \rightarrow 5^{\prime}$ exonuclease (proofreading) and also has the Hot-Start technology increasing the specificity of the reaction ${ }^{11,12,13}$.

The aim of this study was to compare the performance of three Taq DNA polymerases having different properties for the detection of C. trachomatis: a common Taq polymerase (recombinant), Platinum ${ }^{\circledR}$ Taq DNA polymerase and Platinum ${ }^{\circledR}$ Taq DNA polymerase HiFi (Invitrogen, Brazil).

\section{MATERIALS AND METHODS}

\section{SAMPLE}

The population consisted of women cared at 11 of the city's basic healthcare units, during their routine exams. The sample consisted of the participation of 280 women, sequentially registered in this study according to spontaneous demand. This research was conducted in compliance with all ethical issues listed to researches on human beings and approved by the Ethical Research Committee (CAEE $n^{\circ}$ 0010.0.115.000-10) from Universidade Federal do Amazonas. The inclusion criteria were: sexually active women, over 18 years old, who agreed to participate in this study and signed an informed consent (IC) document, regardless of clinical complaints or pregnancy status. Exclusion criteria: hysterectomized women and women undergoing recent antibiotic treatment (three months) or treatment for any recent genital infection. Women were interviewed about clinical, socioeconomic and behavioral factors. All women were submitted for clinical examination, including pelvic one. The samples were collected using vaginal speculum and endocervical brush, packed in a $1.5 \mathrm{~mL}$ microtube containing $400 \mu \mathrm{L}$ of TRIS-EDTA buffer (TRIS-HCl $10 \mathrm{mM}$ and EDTA $1 \mathrm{mM}$ ph 8.0) and frozen immediately.

\section{DNA EXTRACTION}

After thawing at room temperature, the samples were subjected to the process of DNA extraction with the DNeasy Blood \& Tissue Kit (QIAGEN, Germany). Then, a PCR was carried out to check the efficiency of extraction of DNA using the primer pair ISO2G ${ }^{14}$. DNA amplification was carried out in a final volume of $25 \mu \mathrm{L}$, containing $5 \mathrm{U}$ of Platinum Taq DNA Polymerase, $5 \mathrm{pmol}$ of primers pair, $5 \mu \mathrm{L}$ of reaction buffer $5 \mathrm{X}, 25 \mathrm{mM}$ of $\mathrm{MgCl} 2,10 \mathrm{mM}$ of dNTP, $2 \mu \mathrm{L}$ of sample and water. The PCR cycling protocol was: $95^{\circ} \mathrm{C}$ for $2 \mathrm{~min}, 40$ cycles of $95^{\circ} \mathrm{C}$ for $1 \mathrm{~min}, 50^{\circ} \mathrm{C}$ for $1 \mathrm{~min}$ and $72^{\circ} \mathrm{C}$ for $1 \mathrm{~min}$, elongation at $72^{\circ} \mathrm{C}$ for $5 \mathrm{~min}$.

\section{PCR FOR C. trachomatis DNA DETECTION}

$\begin{array}{llr}\text { It was used the primer pair } \mathrm{KL} 1 / \mathrm{KL} 2 \\ \text { (5' }^{\prime} \text { TCCGGAGCGAGTTACGAAGA } & 3^{\prime} / 5^{\prime}\end{array}$
AATCAATGCCCGGGATTGGT 3'15, which amplifies a fragment of $241 \mathrm{bp}$. For the recombinant Taq DNA polymerase enzyme and Platinum Taq DNA polymerase, the reaction final volume was $25 \mu \mathrm{L}$, containing $5 \mathrm{U}$ of enzyme, $5 \mathrm{pmol}$ of each primer, $2.5 \mu \mathrm{L}$ of reaction buffer 10X, $50 \mathrm{mM}$ of $\mathrm{MgCl}_{2}, 10 \mathrm{mM}$ of dNTP, $2.5 \mu \mathrm{L}$ of sample and water. The reactions obeyed the following thermocycle: $94^{\circ} \mathrm{C}$ for $30 \mathrm{~s}, 40$ cycles of $94^{\circ} \mathrm{C}$ for $30 \mathrm{~s}, 54^{\circ} \mathrm{C}$ for $30 \mathrm{~s}$ and $72^{\circ} \mathrm{C}$ for $2 \mathrm{~min}$, ending with $72^{\circ} \mathrm{C}$ for $5 \mathrm{~min}$. For Platinum Taq DNA polymerase $\mathrm{HiFi}$, the reaction final volume was $25 \mu \mathrm{L}$, containing $5 \mathrm{U}$ of enzyme, $5 \mathrm{pmol}$ of each primer, $2.5 \mu \mathrm{L}$ of 
reaction buffer $10 \mathrm{X}, 50 \mathrm{mM}$ of $\mathrm{MgSO}_{4}, 10 \mathrm{mM}$ of dNTP, $2.5 \mu \mathrm{L}$ of sample and water. The reactions followed thermocycle conditions: $94^{\circ} \mathrm{C}$ for $30 \mathrm{~s}$, 40 cycles of $94^{\circ} \mathrm{C}$ for $30 \mathrm{~s}, 54^{\circ} \mathrm{C}$ for $30 \mathrm{~s}$ and $68^{\circ} \mathrm{C}$ for 2 min, ending with $68^{\circ} \mathrm{C}$ for 5 min (Veriti ${ }^{\circledR}$ Thermal Cycler, Applied Biosystems). The PCR products were visualized using a transilluminator on agarose gel $2.0 \%$ stained with GelRed ${ }^{\text {TM }}$ (Biotium Inc., USA), subjected to electrophoresis. A positive control and water were included as a negative control in each reaction.

\section{STATISTICAL ANALYSIS}

The comparison of the PCR results for the three enzymes was done by Chi-square $\left(\chi^{2}\right)$ test, at a significance level of $5 \%$, using the program Statistical Analysis R v3.1.1 (R Foundation for Statistical Computing, 2014).

\section{RESULTS}

Women that participated in this study had a mean age of 36.3 years old (SD $=19.7)$, most of them coming from the Coari City (70.3\%). There was a predominance of women with low educational level (41.7\% had incomplete primary education). Most of them were married or living in stable union with their partner (76.7\%). Mean age at first sexual intercourse was 15.7 years old (SD $=0.7$ ) with an average number of 3.7 children. Nearly half of women (42.8\%) had clinical complaints, their major problems were pain while urinating, pelvic pain, vaginal discharge and itching.

All samples were positive in the PCR detection of human genomic DNA. It was checked that the DNA extraction was effective, followed by PCR for the detection of $C$. trachomatis. The bacterial DNA amplification was detected in four (1.4\%) of the samples when using the recombinant Taq DNA polymerase, seven $(2.5 \%)$ while using Platinum Taq DNA polymerase and 11 (3.9\%) with Platinum Taq DNA polymerase HiFi as displayed in table 1. However, statistical analysis showed no difference among groups $(p=0.186)$.

\section{DISCUSSION}

Infection with C. trachomatis is one of the most prevalent sexually transmitted infections (STI) today, behind only the viral STI. The main problem in the control of this STI is its asymptomatic nature and its difficult diagnosis, has long been considered as a "silent epidemic". With the evolution of diagnostic methods, molecular techniques for detection of this pathogen such as PCR and hybrid capture - showed to be more sensitive and specific than conventional techniques as culture and serology. Molecular techniques, however, are more expensive and require complex laboratory infrastructure, mainly PCR 10,16,17.

The discovery of thermostable DNA polymerase was an important step forward in the development and popularization of PCR, whereby the first enzymes used were thermolabile and demanded that large amounts of enzyme added to each amplification cycle. The innovation to the process, described in the 1980's, came with the use of the DNA thermostable polymerase isolated from the bacterium T. aquaticus hot springs, which was named Taq DNA polymerase. This enzyme was stable at temperatures up to $94^{\circ} \mathrm{C}$, with optimum temperature of $72^{\circ} \mathrm{C}$. Using this thermostable enzyme was possible to automate the process in thermal cycler equipments, which made the technique much easier to be performed ${ }^{12}$.

In this study, it was used PCR for detection of C. trachomatis DNA in cervical specimens using three different DNA polymerases commercially available: Taq DNA polymerase recombinant, Platinum Taq DNA polymerase and Platinum Taq DNA polymerase HiFi. These enzymes represent respectively the evolution in manipulation, cloning and in scale production of these biomolecules, typically biotechnological processes. Also respectively, these enzymes showed an improved performance in detection of $C$. trachomatis in this study. Among the enzymes studied, Platinum Taq DNA polymerase $\mathrm{HiFi}$ showed better performance in relation to the number of amplifications $(3.9 \%)$, followed by the Platinum Taq DNA polymerase $(2.5 \%)$ and recombinant Taq DNA polymerase (1.4\%). Differences in number of samples amplified by each enzyme were not statistically significant $(p=0.186)$.

Table 1 - Results of positive samples by PCR for detection of C. trachomatis using the KL1/KL2 primers according to the different enzymes used

\begin{tabular}{cccc}
\hline Samples & $\begin{array}{c}\text { Taq DNA polymerase } \\
\text { recombinant }\end{array}$ & $\begin{array}{c}\text { Platinum Taq DNA } \\
\text { polymerase }\end{array}$ & Platinum Taq DNA polymerase HiFi \\
\hline $1-280$ & $49,50,178,221$ & $\begin{array}{c}17,41,49,50,178, \\
221,269\end{array}$ & $16,17,41,49,50,58,147,178,221$, \\
269,281
\end{tabular}

$\chi^{2}=3.3636 ; p$-value $=0.186>0.05$. 
$\mathrm{HiFi}$ is the enzyme that showed the highest number of amplifications and it is an evolution of Platinum Taq DNA polymerase, because besides presenting a "hot start" technology, it also has a proofreading activity. Fidelity is defined as the ability to insert the correct nucleotide during the extension, faithfully keeping the Watson-Crick pairing ${ }^{18}$. High fidelity enzymes were designed for optimal performance in PCR fragments that would follow for DNA sequencing, because its $3^{\prime}-5^{\prime}$ exonuclease activity gives a lower probability of errors during amplification, since corrects errors in every new polymerization, with an error rate of only $1.3 \times 10^{-6}$ mutations / bp / duplication ${ }^{12,19}$.

Theoretically, HiFi enzymes ensure high fidelity in nucleotide incorporations, but they are not directly related to a greater sensitivity in the detection of the target DNA in the reaction. In the current study, however, it was found that $\mathrm{HiFi}$ showed a higher sensitivity compared to other enzymes. Similar results were published by Freitas et a ${ }^{20}$ who found $52.8 \%$ of positivity in a population of infertile women using the HiFi enzyme and only $5.7 \%$ in the same samples with another enzyme that did not have this quality.

In turn, the Platinum Taq DNA polymerase showed higher number of positive samples than Taq DNA polymerase recombinant. The "Hot Start PCR" was developed because it was observed that the mixture of all PCR reagents prior to the initial denaturation step increased the chances of nonspecific binding of primers with DNA regions. The main feature of the enzyme Platinum is therefore their property to increase the specificity of the reaction, since the enzyme is blocked by an antibody that only releases to polymerize the DNA strand after the reaction reaches $94^{\circ} \mathrm{C}$ for the first time. Using this enzyme, we avoid nonspecific amplifications at low annealing temperatures ${ }^{13}$. As an alternative to antibody conjugated DNA polymerase, the addition of the enzyme has even been done only after the initial denaturation. Such practice gives similar results to "Hot Start PCR", but requires more manipulation and consequently demands more materials and is more time-consuming ${ }^{11}$. In this study, however, it was observed that the visual analysis of agarose gels and the recombinant enzyme showed a great performance related to the nonformation of nonspecific products, displaying unmistakable unique bands. Although, this process amplified a smaller number of samples comparing with Platinum Taq DNA polymerase and Platinum HiFi.

It is important to mention that these biotechnological improvements of DNA polymerases incur a considerable increase of its cost. These enzymes are sold in concentrations of $5 \mathrm{U} / \mu \mathrm{L}$, considering the costs, each unit of recombinant Taq costs $\mathrm{R} \$ 1,05$, while the Platinum costs $\mathrm{R} \$ 1,60$ and $\mathrm{HiFi}$ costs $\mathrm{R} \$ 8,00$. So it was important that we used different enzymes of the same trademark brand, since we can evaluate the different prices of each one in the same company.

It should be considered another implication on the performance of different Taq DNA polymerases: the difficulty in comparing epidemiological studies. If the Taq DNA polymerases exhibit different sensitivities, the higher or lower rate of detection of $\mathrm{C}$. trachomatis in a population sample will certainly be influenced by the choice of DNA polymerase used. False-negative results generated by the lower sensitivity of the PCR enzyme decrease the visibility of the problem in a population and make it difficult to compare the prevalence of infection among populations.

\section{CONCLUSION}

Even though the statistical differences have not been observed, Platinum Taq DNA Polymerase, Platinum Taq DNA polymerase and common Taq DNA polymerase seem to have slightly different sensitivities. The choice of enzyme in the PCR is very important and the use of less sensitive enzymes in epidemiological studies can generate false negatives results which hide the true prevalence of infection by a pathogen in a population, that also makes it difficult to compare studies using different DNA polymerases.

\section{O uso de diferentes Taq DNA polimerases para a detecção de Chlamydia trachomatis em amostras cervicais}

\section{RESUMO}

INTRODUÇÃO: Chlamydia trachomatis é uma pequena bactéria gram-negativa sexualmente transmissível, que progride de forma assintomática na maioria das pessoas infectadas, causando danos a longo prazo, principalmente no sistema reprodutor feminino. A reação em cadeia da polimerase (PCR) tem sido o método diagnóstico mais utilizado em estudos epidemiológicos recentes, apresentando sensibilidade superior do que outros testes de sensibilidade. Para um bom desempenho da PCR, a escolha de enzimas é importante porque possuem características diferentes que influenciam em seu desenvolvimento. OBJETIVO: Analisar e comparar a detecção de C. trachomatis utilizando três enzimas comerciais Taq DNA polimerases em 280 amostras cervicais. MÉTODOS: As enzimas utilizadas foram: Taq DNA polimerase recombinante (Invitrogen, EUA), Platinum Taq DNA polimerase (Invitrogen, EUA) e Platinum Taq DNA polimerase de alta fidelidade (Invitrogen, EUA). RESULTADOS: Foram analisadas 280 amostras cervicais de mulheres que vivem na Cidade de Coari, Estado do Amazonas, Brasil, cuja média de idade era de 36,3 anos, a maioria tinha baixa escolaridade, tendo a primeira relação sexual na média de 15,7 anos de idade ( $D P=0,7)$ e com em média 3,7 filhos. Destas, $42,5 \%$ relatavam queixas clínicas durante a visita, entre as quais predominavam o corrimento vaginal, coceira, dor pélvica e dor ao urinar. Do total de 280 amostras, quatro $(1,4 \%)$ foram positivas usando Taq DNA polimerase recombinante, sete $(2,5 \%)$ utilizando a enzima Platinum Taq DNA polimerase e 11 (3,9\%) amostras foram positivas utilizando Platinum Taq DNA polimerase de alta fidelidade. A análise estatística não mostrou diferença entre os grupos $(p=0,186)$. CONCLUSÃO: Taq DNA polimerases com propriedades distintas apresentam diferenças no desempenho na deteç̧ão de C. trachomatis.

Palavras-chaves: Taq Polimerase; Chlamydia trachomatis; Técnicas de Diagnóstico Molecular. 


\section{El uso de diferentes Taq DNA polimerasas para la detección de Chlamydia trachomatis en muestras cervicales}

\section{RESUMEN}

INTRODUCCIÓN: Chlamydia trachomatis es una pequeña bacteria gram-negativa sexualmente transmisible, que progresa de forma asintomática en la mayoría de las personas infectadas, causando daños a largo plazo, principalmente en el sistema reproductor femenino. La reacción en cadena de la polimerasa (PCR) ha sido el método diagnóstico más utilizado en estudios epidemiológicos recientes, presentando sensibilidad superior a otras pruebas de sensibilidad. Para un buen desempeño de la PCR, la elección de enzimas es muy importante porque poseen características diferentes que influyen en su desarrollo. OBJETIVO: Analizar y comparar la detección de C. trachomatis utilizando tres enzimas comerciales Taq DNA polimerasas en 280 muestras cervicales. MÉTODOS: Las enzimas utilizadas fueron: Taq DNA polimerasa recombinante (Invitrogen, EUA), Platinum Taq DNA polimerasa (Invitrogen, EUA) y Platinum Taq DNA polimerasa de alta fidelidad (Invitrogen, EUA). RESULTADOS: Se analizaron 280 muestras cervicales de mujeres que viven en la ciudad de Coari, Estado de Amazonas, Brasil, cuyo promedio de edad era de 36,3 años, la mayoría con baja escolaridad, habiendo tenido la primera relación sexual en el promedio de 15,7 años de edad (DP $=0,7)$ y con número de hijos de 3,7 en un promedio. Un 42,5\% relataba quejas clínicas durante la visita, entre las que predominaban, flujo vaginal, picazón, dolor pélvico y dolor al orinar. Del total de 280 muestras, cuatro $(1,4 \%)$ fueron positivas usando Taq DNA polimerasa recombinante, siete $(2,5 \%)$ utilizando la enzima Platinum Taq DNA polimerasa y 11 (3,9\%) muestras fueron positivas utilizando Platinum Taq DNA polimerasa de alta fidelidad. El análisis estadístico no mostró diferencia entre los grupos $(p=0,186)$. CONCLUSIÓN: Taq DNA polimerasas con propiedades distintas presentan diferencias en el desempeño en la detección de C. trachomatis.

Palabras clave: Polimerasa Taq; Chlamydia trachomatis; Técnicas de Diagnóstico Molecular.

\section{REFERENCES}

1 Seadi CF, Oravec R, von Poser B, Cantarelli W, Rosseti ML. Diagnóstico laboratorial da infecção pela Chlamydia trachomatis: vantagens e desvantagens das técnicas. J Bras Patol Med Lab. 2002;38(2):125-33.

2 Clarke IN. Evolution of Chlamydia trachomatis. Ann N Y Acad Sci. 2011 Aug;1230:E1 1-8.

3 Herkenhoff ME, Galke R, Vieira LL, Ferreira PS, Pitlovanciv AK, Remualdo VR. Prevalence of Chlamydia trachomatis in endocervical samples by PCR in São Paulo and Santa Catarina. J Bras Patol Med Lab. 2012 Oct;48(5):323-7.

4 Malhotra M, Sood S, Mukheriee A, Muralidhar S, Bala M. Genital Chlamydia trachomatis: an update. Indian J Med Res. 2013 Sep;138(3):303-16.

5 Rocha DAP, Barbosa Filho RAA, Mariño JM, Santos CMB. "Hidden" sexually transmitted infection among women in primary health care health services, Amazonas, Brazil. Int J STD AIDS. 2014 Oct;25(12):878-86.

6 Jalil EM, Pinto VM, Benzaken AS, Ribeiro D, Oliveira EC, Garcia EG, et al. Prevalência da infecção por clamídia e gonococo em gestantes de seis cidades brasileiras. Rev Bras Ginecol Obstet. 2008 dez;30(12):614-9.

7 Ramos BR, Polettini J, Marcolino LD, Vieira EP, Marques MA, Tristão AR, et al. Prevalence and risk factors of Chlamydia trachomatis cervicitis in pregnant women at the genital tract infection in obstetric unit care at Botucatu Medical School, São Paulo State University - UNESP, Brazil. J Low Genit Trac Dis. 2011 Jan;15(1):20-4.
8 Lima YAR, Turchi MD, Fonseca ZC, Garcia FLB, Cardoso FAB, Reis MNG, et al. Sexually transmitted bacterial infection among young women in Central Western Brazil. Int J Infect Dis. 2014 Aug;25:16-21.

9 Magalhães PAF, Miranda CAN, Lima EG, Moizés RNC, Lima DBS, Cobucci RNO, et al. Genital tract infection with Chlamydia trachomatis in women attended at a cervical cancer screening program in Northeastern from Brazil. Arch Gynecol Obstet. 2015 May;291 (5): 1095-102.

10 Puolakkainen M. Laboratory diagnosis of persistente human chlamydial infection. Front Cell Infect Microbiol. 2013 Dec;3(99):1-8.

11 Arezi B, Xing W, Sorge JA, Hogrefe HH. Amplification efficiency of thermostable DNA polymerases. Anal Biochem. 2003 Oct;321 (2):226-35.

12 Haiki GD, Rakshit SK. Developments in industrially important thermos-table enzymes: a review. Bioresour Technol. 2003 Aug;89(1):17-34.

13 Ludwig JB. Clonagem, expressão e produção da DNA polimerase de alta fidelidade em Pyrococcus furiosus [monografia]. Porto Alegre (RS): Universidade Federal do Rio Grande do Sul; 2010.

14 Pontes IM. Desenvolvimento de novos marcadores microssatélites para análise genética em humanos [dissertação]. São Carlos (SP): Universidade Federal de São Carlos; 2002.

15 Mahony JB, Luinstra KE, Sellors JW, Chernesky MA. Comparison of plasmid-and chromossome-based polymerase chain reaction assays for detecting Chlamydia trachomatis nucleic acids. J Clin Microbiol. 1993 Jul;31 (7):1753-8. 
16 Rossetti ML, Silva CMD, Rodrigues JJS. Doenças infecciosas: diagnóstico molecular. Rio de Janeiro: Guanabara Koogan; 2006.

17 Oliveira ML, Amorim MMR, Souza ASR, Albuquerque LCB, Costa AAR. Chlamydia infection in patients with and without cervical intra-epithelial lesion tested by real-time PCR vs. direct immunofluorescence. Braz J Infec Dis. 2008 Aug;12(4):324-8.

18 Billes BD, Connolly BA. Low-fidelity Pirococcus furiosus DNA polymerase mutants useful in error-prone PCR. Nucleic Acids Res. 2004 Dec;32(22):e176.
19 Cline J, Braman JC, Hogrehe HH. PCR fidelity of Pfu DNA polymerase and other thermostable DNA polymerases. Nucleic Acids Res. 1996 Sep;24(18):3546-51.

20 Freitas NSL, Borborema-Santos CM, Neves BSN, Oliveira CMC, Astolfi Filho S. High prevalence detection of Chlamydia trachomatis by polymerase chain reaction in endocervical samples of infertile women attending University Hospital in ManausAmazonas, Brazil. Gynecol Obstet Invest. 2011 Dec;72(4):220-6. 